\title{
Criminologie
}

\section{Bibliographie générale sur la probation}

\section{Jacqueline De Plaen}

Volume 12, numéro 2, 1979

Probation : aide ou contrainte ?

URI : https://id.erudit.org/iderudit/017111ar

DOI : https://doi.org/10.7202/017111ar

Aller au sommaire du numéro

Éditeur(s)

Les Presses de l'Université de Montréal

ISSN

0316-0041 (imprimé)

1492-1367 (numérique)

Découvrir la revue

Citer ce document

De Plaen, J. (1979). Bibliographie générale sur la probation. Criminologie, 12(2), 101-105. https://doi.org/10.7202/017111ar d'utilisation que vous pouvez consulter en ligne.

https://apropos.erudit.org/fr/usagers/politique-dutilisation/ 


\section{BIBLIOGRAPHIE GENERALE}

SUR LA PROBATION

Jacqueline De Plaen *

Le présent relevé ne se prétend pas exhaustif. Il a néanmoins l'avantage de présenter à titre complémentaire des travaux qui n'ont pas été mentionnés par les auteurs du présent numéro. De plus, nous nous sommes limités aux publications des cinq dernières années, jugeant les documents antérieurs suffisamment connus des lecteurs.

\section{PUBLICATIONS CANADIENNES ET QUÉBECOISES}

ARSENAULT, R. (1974) : Service de probation et justice criminelle : perception des probationnaires, Mémoire de mâ̂trise ès sciences sociales (Criminologie), Montréal, Université de Montréal, Ecole de criminologie.

BÉLIVEAU, P., J. BELLEMASE et J.-P. LUSSIER (1977) : - La mise en liberté provisoire par voie judiciaire *, La revue du Barreau, 37 : 3, 353-378.

BRAVO-DAVILA, L.A. (1978) : Bases pour le développement d'un système de probation au Vénézuela, Mémoire de maîtrise ès sciences sociales (Criminologie), Montréal, Université de Montréal. Ecole de criminologie.

CANADA. COMMISSION DE RÉFORME DU DROIT (1976) : Le processus de libération conditionnelle, Ottawa, Approvisionnements et Services.

CANADA. COMMISSION DE REFORME DU DROIT (1976) : Principes directeurs des sentences et mesures non sentencielles dans le processus pénal, Ottawa, Approvisionnements et Services.

CANADA. MINISTĖRE DU SOLLICITEUR GÉNÉRAL (1978) : Lois choisies sur la probation au Canada, par J. Trépanier et E. Osborne, Ottawa, Ministère du Solliciteur Général.

EMOND, M. (1975) : Probation et mesures connexes en relation avec la loi, Mémoire de maîtrise ès sciences sociales (Cri-

* Jacqueline De Plaen est responsable du service de documentation du Centre international de criminologie comparée. 
minologie), Montréal, Université de Montréal, École de criminologie.

ONTARIO. MINISTRY OF CORRECTIONAL SERVICES (1978) : The Adult Probationer in Ontario, Ontario, Ministry of Correctional Services.

ONTARIO. MINISTRY OF CORRECTIONAL SERVICES (1977) : The Concerns and Attitudes of Probation Officers. A Study of Perception, Ontario, Ministry of Correctional Services.

ONTARIO. MINISTRY OF CORRECTIONAL SERVICES (1976) : Report to the Minister, Ontario, Ministry of Correctional Services.

ONTARIO. MINISTRY OF CORRECTIONAL SERVICES (1975) : Probation and Parole Manual, January, Ontario, Ministry of Correctional Services.

ONTARIO. MINISTRY OF CORRECTIONAL SERVICES (1974) : Probation and Aftercare Manual, February, Ontario, Ministry of Correctional Services.

ONTARIO. MINISTRY OF CORRECTIONAL SERVICES (1973) : Report of the Committee on Staff Training and Development Services Probation and Aftercare Services, Ontario, Ministry of Correctional Services.

ST-ONGE, P. (1978) : \&es officiers de probation et de liberation conditionnelle : leurs pouvoirs et limites s, Crime et Justice, $6: 3.181-183$.

TREPANIER, J. (1978) : The Characteristics of Probation Offcers in relation to the Decision-making Process in the Presentence Inquiry. Dissertation, London.

2. PUBLICATIONS AMERICAINES ET ETRANGERES

BAMFORD, M. (1975) - Presentation of Court Reports s, Social Work Today, 6. p. 642.

BANKS, J., R.L. RARDIN (1978) : « Evaluation Practice in Adult Intensive Special Probation s, Federal Probation, 42 : 1. 16-21.

BARTHOLOMEW, A.A., D.E. LORD (1975) : e The Presentence Report Another Look ,, Howard Journal of Penology and Crime Prevention, 14. 23-30. 
BEAN, P. (1976) : Rehabilitation and Deviance, London, Routledge and Kegan Paul.

BRAZILL, R. (1976) : \& Recent Developments in the Confidentiality of Pre-sentence Reports s, Albany Law Review, 40. 619-645.

CARTER, R.M., L.T. WILKINS (1970) : Probation and Parole, New York, John Wiley and Sons, Inc.

COHEN, Y. (1976) : - Staff Supervision in Probation », Federal Probation, $40: 3.17-23$.

COMMISSION ON ACCREDITATION FOR CORRECTIONS (1977) : Manual of Standards for Adult Probation and Parole Field Services, Rockville, Md.

COMMUNITY SERVICE SOCIETY OF NEW YORK (1978) : Is New York Takeover of Probation Services a Good Idea? Prepared for the Committee on Criminal and Juvenile Justice, By D.R. Gordon, New York.

DAUNTON-FEAR, M.W. (1975) : Social Inquiry Reports : Comprehensive and Reliable? > British Journal of Criminology, 15. 128-139.

GREENWALD, F. (1978) : International Probation - The Time is Now s, Prison Journal, $58: 2.38-42$.

HAGAN, J. (1977) : * Criminal Justice in Rural and Urban Communities : A Study of the Bureaucratization of Justice >, Social Forces, 55. 597-612.

HERBERT, L., D. MATHIESON (1975) : Report for Courts, Thorson Heath (Surrey), National Association of Probation Officers.

HOLLAND, T.R., N. HOLT (1976) : * Offenders' Caracteristics Versus Decision-makers' Attitudes as Determinants of the Outcome of Presentence Evaluations \$, Psychological Reports, 39. 267-274.

JARVIS, R.V. (1977) : « Developments in the Probation and After Care Services in England and Wales \$, International Journal of Offender Therapy and Comparative Criminology, 21. 105-113.

KILPATRIC, D., J. BRUMMEL (1976) « Sentencing Study >, Washington Law Review, 52. 103-119. 
KOZA, P.A., A.M. DOOB (1975) : « Some Empirical Evidence on Judicial Interim Release Proceedings \$, Criminal Law Quarterly, 17. 258-272.

MAHONEY, J.C., F.B. RAYMOND (1977) : * A Standardized Presentence Report : One State's Response s, Federal Probation, $41: 2$. 40-42.

MATHIESON, D. (1975) : * Probation Officers : Sentencers of the Future? >, Justice of the Peace, 139. 162-164.

PHILLIPS, M. (1976) : « Probation Officers », New Society, 37. p. 401.

POTTER, J. (1977) « Shock Probation : A Little Taste of Prison ", Corrections Magazine, 3 : 4. 49-55.

RANDOLPH, D.L. (1978) : \& Goal Facilitation as a Probation Teams », Federal Probation, 42 : 2. 26-32.

SCHOONMAKER, M.H., J.S. BROOKS (1975) : * Women in Probation and Parole, 1974 ,, Crime and Delinquency, April, 109-115.

SCOTT, R.J. (1978) : « Contract Programming in Probation : Philosophical and Experimental Bases for Building a Model », Justice System Journal, 4 : 1. 49-70.

SEGAL, B., G. HAWES (1976) : Correctional Manpower Planning, Training and Development Project, National Advisory Network on Correctional Manpower Planning, Training and Development.

THORPE, J., K. PEASE (1976) : * The Relationship Between Recommendations Made to the Court and Sentences Passed \$, British Journal of Criminology, 16. 393-394.

U.S. DEPARTMENT OF JUSTICE. LEAA. NILECJ (1977) : Evaluation of Intensive Special Probation Projects. NEP. Phase 1 Report, Washington, D.C., Department of Justice.

U.S. DEPARTMENT OF JUSTICE. LEAA. NILECJ (1975) : The Volunteer Probation Counselor Program, Washington, D.C., Department of Justice.

WALDRON, J.A., H.R. ANGELINO (1977) : * Shock Probation : A Natural Experiment on the Effect of a Short Period of Incarceration ", Prison Journal, $57: 1$. 45-52. 
WOOD, W.T. (1978) : Multnomah County Probation Teams s, Federal Probation, $42: 3$. 7-10.

WOOD, W.T. (1978) : Blueprint for Developing Probation Teams *, Federal Probation, 42 : 2. 15-19.

ZAENGLEIN-SENGER, M.M. (1978) : Social Psychological Profile of Volunteer Probation Officers: A Preliminary Report, Michigan State University. 